GHANA JOURNAL OF DEPARTMENT OF HEALTH, PHYSICAL EDUCATION AND RECREATION, SPORTS AND DANCE (GJOHPERSD)

Volume 7 \& 8, Year 2014 \& 2015

A JOURNAL OF THE DEPARTMENT OF HEALTH, PHYSICAL EDUCATION AND RECREATION (HPER)

UNIVERSITY OF CAPE COAST

GHANA, WEST AFRICA 


\title{
AWARENESS OF THE BENEFITS OF GINGER USE AMONG STUDENTS OF NIGERIA ARMY SCHOOL OF EDUCATION, SOBI-ILORIN, KWARA STATE
}

\author{
${ }^{* 1}$ Dominic, Olufunmilola L., ${ }^{2}$ Muhammad Abdullahi, M., \& \\ ${ }^{2}$ Seidina, Iliasu $Y$. \\ ${ }^{1}$ Department of Health, Physical Education and Recreation, \\ University of Cape Coast, Ghana. \\ ${ }^{2}$ Department of Human Kinetics Education, University of Ilorin, \\ Ilorin Nigeria.
}

*Corresponding Author: lolafunmidom@gmail.com

\begin{abstract}
The objective of this study was to determine the level of awareness, knowledge of benefits and use of ginger among the students of the Nigerian Army School of Education (NASE), Sobi-Ilorin Kwara State. The descriptive survey design was used to elucidate the awareness, knowledge of benefits and practice of ginger use. The population was all 350 students of NASE, Ilorin. They were purposively selected, from which 337 validly participated. The instrument for data collection was a validated researcherstructured questionnaire. Test retest reliability was conducted and PPMC coefficient $(r=0.72)$ was obtained. Frequency and percentage were used for demographic data while t-test was used for testing the hypotheses at 0.05 alpha level. The result revealed that NASE, Ilorin students were highly aware of ginger, 312 (92.6\%). There was significant difference between soldiers and officers in; awareness $n=337, t(335)=4.94, p=0.001, \eta^{2}=$ .007 ; health benefits $n=337, t(335)=2.92, p=0.004, \eta^{2}=.002$ and performance purposes $n=337, t(335)=2.48, p=0.001, \eta^{2}=$ .002. It was concluded that majority of NASE students are aware
\end{abstract}


Awareness of the benefit of Ginger use among Students of Nigeria Army School of Education, Sobil-Ilorin, Kwara State

of ginger, which they mainly consumed as drinks. Further study is necessary to ascertain the size of benefits and the best way ginger use would enhance the health and job performance of military personnel.

Keywords: Awareness, Ginger, Health, Performance, Supplements

82 A Journal of the Department of Health, Physical Education and Recreation 


\section{Introduction}

Ginger, a natural spice, is commonly use among Nigerian populace for several purposes. Some of these purposes includes spice, herbal remedy, flavour and treatment of different illnesses. Over the last few years, there has been a substantial rise in the use of natural or alternative medicine among adults. These complementary and alternative medicine in the form of dietary supplements and herbal remedies are subscribed to on the premise that they have beneficial effects without advice from the physician (Cohen, Ek \& Pan, 2002). Ginger (Zingiber officinale Roscoe, Zingiberaceae) has been in existence for thousands of years and it is one of the most commonly consumed dietary condiments in the world (Surh, Park, Chun, Lee, Lee\& Lee, 1999). Ginger contains many bioactive components which are believed to exert a variety of remarkable pharmacological and physiological activities like treatment of numerous ailments, such as colds, nausea, arthritis, muscle pain, migraine, and hypertension (Nicoll \& Henein, 2009; Ali, Blunden, Tanira \& Nemmar, 2007).

The major producers of Ginger today are China and tropical/subtropical places in Asia, Brazil, Jamaica and Nigeria (Osabor, Bassey \& Umoh, 2015). The ginger plant is approximately $30-60 \mathrm{~cm}$ tall and is extremely rare to find in the wild. Ginger's current name comes from the Middle English gingivere, but this spice dates back over 3000 years to the Sanskrit word srngaveram, meaning "horn root," based on its appearance. In Greek, it was called ziggiberis, and in Latin, zinziberi. Indians and Chinese are believed to have produced ginger as a tonic root for over 5000 years to treat many ailments, and this plant is now cultivated throughout the humid tropics, with India being the largest producer. Ginger was used as a flavouring agent long before history was formally recorded (Utuk, 2017).

Ginger was an exceedingly important article of trade and was exported from India to the Roman Empire over 2000 years ago, where it was especially valued for its medicinal properties. It continued to be a highly sought after commodity in Europe even after the fall of the Roman Empire, with Arab merchants 
Awareness of the benefit of Ginger use among Students of Nigeria Army School of Education, Sobil-Ilorin, Kwara State

controlling the trade in ginger and other spices for centuries. In the thirteenth and fourteenth centuries, the value of a pound of ginger was equivalent to the cost of a sheep. During the medieval times, it was imported in preserved form to be used in sweets. Queen Elizabeth I of England is credited with the invention of the gingerbread man, which become popular Christmas treat (Ferguson, 2014).

At least 115 constituents have been identified by a variety of analytical processes in fresh and dried ginger varieties. Gingerols are the major constituents of fresh ginger, gingerols are founds lightly reduced in dry ginger, whereas the concentrations of shogaols, which are the major gingerol dehydration products, are more abundant in dry ginger than in fresh ginger (Jolad, Lantz, Chen, Bates \& Timmermann, 2005). Ginger contains at least 14 bioactive compounds, including 4-gingerol, 6-gingerol, 8-gingerol, 10-gingerol, 6-paradol, 14-shogaol,6-shogaol, 1-dehydro-10gingerdione, 10gingerdione, hexahydrocurcumin, tetrahydrocurcumi $\mathrm{n}$, gingerenone A, 1,7-bis-(4' hydroxyl-3' methoxyphenyl)-5methoxyhepthan-3-one and methoxy- 10-gingerol (Koh, Kim \& Kim, 2009). Scientists have reported that the proportion of each individual component in a sample of ginger depends on country of origin, commercial processor and whether the ginger is fresh, dried, or processed (Bailey-Shaw et al, 2008; Schwertner, Rios \& Pascoe, 2006)

The most common and well-established use of ginger throughout history is utilization in alleviating symptoms of nausea and vomiting. Quimby (2007) and Thompson and Potter (2006) reported via several controlled studies that ginger is generally effective as an antiemetic (drug that control vomiting and nausea). The effectiveness of ginger as an antiemetic has been attributed to its carminative (an herb or preparation that prevent gas formation) effect, which helps to break up and expel intestinal gas. This idea was supported by the results of a randomized, double-blind trial in which healthy volunteers reported that ginger effectively accelerated gastric emptying and stimulated antral contractions (Wu, Rayner \& Chuah,2008). Ginger root contains a very high 
level $(3.85 \mathrm{mmol} / 100 \mathrm{~g})$ of total antioxidants, surpassed only by pomegranate and some types of berries (Halvorsen, 2002).Topic et al (2002) reported that ginger reduced age-related oxidative stress and ethanol induced hepatotoxicity (chemical-driven liver damage). The work of El-Sharaky, Newairy, Kamel and Eweda (2009); Ahmed et al (2008) also noted that ginger protects the levels of reduced glutathione (antioxidant) and suppresses lipid peroxidation (a process by which free radicals steal electron from cell membrane there by causing damage to the cell).

One of the many health claims attributed to ginger is its ability to decrease inflammation, swelling and pain. Young et al (2005) and Minghett, Sosa and Cilurzo (2007) reported that 6gingerol, a dried ginger extract and a dried gingerol-enriched extract exhibit some level of analgesic and potent antiinflammatory effects. Aside the anti-inflammatory effect, ginger, it is also effective against osteoarthritis and rheumatism Reginster, Gillot, Bruyere and Henrotin (2000). There are in vitro and animal data supports its benefits in alleviating cardiovascular disease, as well as the anti-inflammatory, antioxidant, antiplatelet, hypotensive and hypolipidemic effects of this condiment are well documented (Nicoll \& Henein, 2009). An aqueous ginger extract was reported to induce a dose-dependent decrease in arterial blood pressure in a variety of animal models (Ghayur \& Gilani, 2005). Furthermore, a ginger extract inhibited airway contraction and associated calcium signalling, possibly by blocking plasma membrane in calcium channels. Dried form of ginger was also beneficial in treating dementia, including Alzheimer's disease (Ghayur et al., 2008). El-Abhar, Hammad and Gawad (2008) reported that in rats, ginger extract alleviated the symptoms of acetic acid-induced ulcerative colitis.

Ginger is found virtually in every market in Nigeria either in dried or fresh form. The plant has a high medicinal and food value. It is cultivated in large quantities by many farmers in northern part of Nigeria (Kaduna, Benue, Nassarawa, Niger and Gombe). 
Awareness of the benefit of Ginger use among Students of Nigeria Army School of Education, Sobil-Ilorin, Kwara State

The ginger root is used in Nigeria as herbal medicine and in homes as spice for pap, flavour soup and other delicacies, drinks and treatment of various illness (Utuk, 2017).

Orally, ginger is usually well tolerated when used in typical doses. However, higher doses of $5 \mathrm{~g}$ per day increase the risk of side effects and decrease tolerability. Common side effects of ginger include abdominal discomfort, heartburn, diarrhoea and a pepper like irritant effect in the mouth and throat. Topically, ginger can cause dermatitis in sensitive individuals (Akram et al, 2011). This implies that ginger must not be consumed in excess so that its health benefits will not be compromised.

Nutrients in the form of dietary supplement can improve performance during physical activity. Athletes across Nigeria commonly take different types of supplements to boost their performance during physical activity or competitive sports including local supplement such as Zobo, Kunu and herbs (Amina et al, 2014). These local supplement are virtually found in every market in Nigeria most especially ginger, which is a commonly consumed dietary spice. However, the use of ginger as supplement in boosting performance as well as recovery was supported by limited studies. This was evident in the work of Mashhadi, et al (2013); which revealed that ginger has effect as anti-oxidative and anti-inflammatory in promoting health and physical activity. Furthermore, it was buttressed by Nafiseh et al (2013), that ginger can increase performance in exercise. Melissa, Matsumura, Gerald, Zavorsky, James (2015) also reported that ginger can delay the onset of muscle soreness and enhance recovery of damage muscle.

Several researches have confirmed ginger to have beneficial role in the biological system ranging from alleviation of respiratory illnesses to enhancing the immune system and physical alertness as well as performance exercise (Nafiseh et al, 2013). The researcher observed that the use of ginger is not new in NASE Sobi-Ilorin Kwara State which implies some level of awareness among the students. This might improve their day-to-day activities, since their profession requires physical alertness and optimal performance if they must survive. 
However, there is no empirical evidence to support this assumption. Therefore, it became imperative to find out the participants' level of ginger awareness, the benefits and differences in ginger use between officers and soldiers.

\section{Methods}

The descriptive research survey was adopted. The population was all the registered 350 male and female students of NASE Sobi-Ilorin, Kwara State, Nigeria. All the students were purposively selected for the study because they possess similar characteristics and met the inclusion criteria of being military personnel, studying and resident at NASE Sobi-Ilorin. The valid sample was 337 respondents that consisted of 232 soldiers and 105 officers with an age range of 18-50 years. A researcher-structured questionnaire which contained 30 items that were divided into sections A and B was used for data collection. Section A dealt with demographic data of the participants while section B dealt with level of awareness and benefits of ginger use. The questionnaire was validated and subjected to test retest reliability which was conducted at the base of 222 Battalion, Nigerian Army Sobi-Ilorin with two weeks interval between the first and second administration. Pearson Product Moment Correlation (PPMC) was used to determine the reliability level and $r=0.72$ was obtained. The participants were duly enlightened and informed consent was obtained from them before data collection. Frequency and percentage were used for analysis of demographic characteristics and answering the research questions while t-test was used to test the hypotheses at 0.05 level of significance. All the statistical analysis was conducted using Statistical package for Social Sciences (SPSS Version 20.0). 
Awareness of the benefit of Ginger use among Students of Nigeria Army School of Education, Sobil-Ilorin, Kwara State

\section{Results}

Table 1: Level of Ginger Awareness among NASE Students in Sobi-Ilorin, Kwara State

\begin{tabular}{|c|c|c|c|}
\hline Variable & $\begin{array}{l}\text { All } \\
\text { Students } \\
\mathbf{N}(\%)\end{array}$ & $\begin{array}{l}\text { Officers } \\
\mathbf{N}(\%)\end{array}$ & $\begin{array}{l}\text { Soldiers } \\
\mathbf{N}(\%)\end{array}$ \\
\hline \multicolumn{4}{|c|}{$\begin{array}{l}\text { Have you ever seen } \\
\text { ginger? }\end{array}$} \\
\hline Yes & $\begin{array}{l}312 \\
(92.6 \%)\end{array}$ & $99(94.3 \%)$ & $\begin{array}{l}213 \\
(91.8 \%)\end{array}$ \\
\hline No & $\begin{array}{l}25 \\
(7.4 \%)\end{array}$ & $6(5.7 \%)$ & $19(8.2 \%)$ \\
\hline Total & $\begin{array}{l}337 \\
(100 \%)\end{array}$ & $105(100 \%)$ & $\begin{array}{l}232 \\
(100 \%)\end{array}$ \\
\hline \multicolumn{4}{|c|}{$\begin{array}{l}\text { Do you take ginger } \\
\text { drink? }\end{array}$} \\
\hline Yes & $\begin{array}{l}274 \\
(81.3 \%)\end{array}$ & $91(86.7 \%)$ & $\begin{array}{l}183 \\
(78.9 \%)\end{array}$ \\
\hline No & $\begin{array}{l}47 \\
(13.9 \%)\end{array}$ & $14(13.3 \%)$ & $\begin{array}{l}49 \\
(21.1 \%)\end{array}$ \\
\hline Total & $\begin{array}{l}337 \\
(100 \%)\end{array}$ & $\begin{array}{l}105 \\
(100 \%)\end{array}$ & $\begin{array}{l}232 \\
(100 \%)\end{array}$ \\
\hline \multicolumn{4}{|c|}{$\begin{array}{l}\text { How often do you use } \\
\text { ginger? }\end{array}$} \\
\hline Daily & $\begin{array}{l}79 \\
(23.4 \%)\end{array}$ & $20(19.0 \%)$ & $\begin{array}{l}59 \\
(25.4 \%)\end{array}$ \\
\hline Weekly & $\begin{array}{l}80 \\
(23.7 \%)\end{array}$ & $29(27.6 \%)$ & $\begin{array}{l}51 \\
(22.0 \%)\end{array}$ \\
\hline Monthly & $\begin{array}{l}52 \\
(15.4 \%)\end{array}$ & $19(18.1 \%)$ & $\begin{array}{l}33 \\
(14.2 \%)\end{array}$ \\
\hline Can't remember & $\begin{array}{l}99 \\
(29.6 \%)\end{array}$ & $37(35.2 \%)$ & $\begin{array}{l}85 \\
(36.6 \%)\end{array}$ \\
\hline Total & $\begin{array}{l}337 \\
(100 \%)\end{array}$ & $\begin{array}{l}105 \\
(100 \%)\end{array}$ & $\begin{array}{l}232 \\
(100 \%)\end{array}$ \\
\hline
\end{tabular}

Result in table 1 revealed that majority of NASE, SobiIlorin students $92.6 \%$ (312) have seen ginger before, 7.4\% (25) have not; $81.3 \%$ (274) of them take ginger drink while $13.9 \%$ (47) of them did not. In addition, $23.4 \%$ (79) of them use ginger daily, $23.7 \%$ (80) use it weekly, $15.4 \%$ (52) use it monthly, while $29.6 \%$ (99) cannot remember how often they use it. However soldiers use ginger products daily while officers use more weekly and monthly. Further consideration by job status shows that majority of the officers $94.3 \%$ (99) have seen ginger while just 5.7\% (6) have not. 
Among the soldiers, 91.8\% (213) of them have seen ginger while $8.2 \%$ (19) have not. Majority of the officers $86.7 \%$ (91) drink ginger while $13.3 \%$ (14) did not. For the soldiers, $78.9 \%$ (183) of them drink ginger while $21.1 \%$ (49) of them did not. This result implies that students of NASE, Sobi-Ilorin have good awareness level of ginger and its products, and ginger is part of the nutrients in the diets they consume.

Table 2: Benefits of Ginger Use among Students of NASE, Sobi-Ilorin, Kwara State

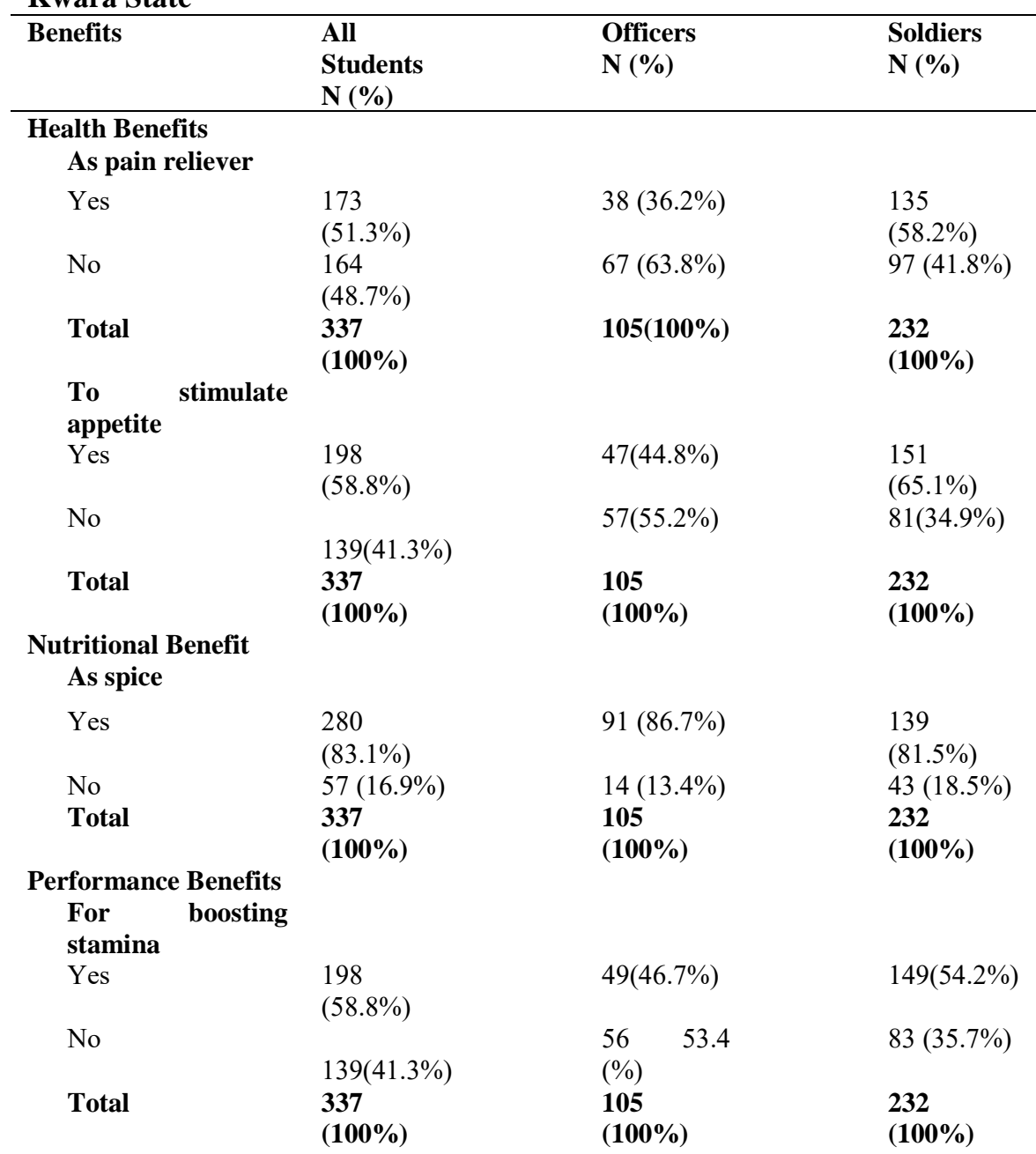


Awareness of the benefit of Ginger use among Students of Nigeria Army School of Education, Sobil-Ilorin, Kwara State

To be active and

alert

Yes

195

$51(48.6 \%)$

144

$(57.9 \%)$

No

142

Total

Table 2 reveals that the respondents used ginger for different purposes such as health (pain reliever and stimulating appetite), nutritional (spice) and performance (boosting stamina, activeness and alertness).Majority of the students $173(51.3 \%)$ used ginger as pain reliever, among which, 36.2\% (38) of them were officers and $58.2 \%$ (135) of them were soldiers. The result also shows that majority of the students $58.8 \%$ (198) used ginger for boosting stamina. These comprised of $46.7 \%$ (49) officers and $14954.2 \%$ (149) soldiers. Majority of the students used ginger for stimulating appetite; these comprised of $44.8 \%$ (47) officers and $65.1 \%$ (151) soldiers. Furthermore, majority of the students used ginger to improve alertness and activeness for optimal performance in their job. Among these were $48.6 \%$ (51) officers and $62.1 \%$ (144) soldiers.

Table 3: t-test Analysis for Difference in Ginger Use between Officers and Soldiers

\begin{tabular}{|c|c|c|c|c|c|c|c|c|}
\hline Variables and Groups & $\mathbf{n}$ & $\begin{array}{l}M \pm \\
\text { SD }\end{array}$ & MD & $\mathbf{t}$ & df & SED & $\eta^{2}$ & Sig \\
\hline \multicolumn{9}{|l|}{ Ginger Awareness: } \\
\hline Soldiers & 232 & $\begin{array}{l}9.32 \\
\pm \\
1.32\end{array}$ & 1.67 & 4.94 & 335 & 1.02 & .007 & 0.001 \\
\hline Officers & 105 & $\begin{array}{l}7.65 \\
\pm \\
0.22\end{array}$ & & & & & & \\
\hline Total & 337 & $\begin{array}{l}16.97 \\
\pm \\
1.54\end{array}$ & & & & & & \\
\hline \multicolumn{9}{|c|}{$\begin{array}{l}\text { Health Benefits from Ginger } \\
\text { Intake: }\end{array}$} \\
\hline Soldiers & 232 & 10.60 & 0.94 & 2.92 & 335 & 0.32 & .002 & 0.004 \\
\hline
\end{tabular}

90 A Journal of the Department of Health, Physical Education and Recreation 


\begin{tabular}{lll}
\hline & & \pm \\
Officers & 2.56 \\
& 105 & 11.53 \\
& \pm \\
Total & 2.68 \\
& $\mathbf{3 3 7}$ & $\mathbf{2 2 . 1 3}$ \\
& \pm \\
& $\mathbf{5 . 2 4}$
\end{tabular}

Performance Benefits from

Ginger Intake:

Soldiers

$\begin{array}{llllllll}232 & \begin{array}{l}5.13 \\ \pm \\ \\ 1.40\end{array} & 0.45 & 2.48 & 335 & 0.18 & .002 & 0.001 \\ & & & & & & \end{array}$

Officers

$105 \quad 5.58$

$\pm$

1.54

Total

$337 \quad 10.71$

$\pm$

2.94

$\mathrm{p} \leq 0.05$

Table 3 shows result of t-test analyses conducted to examine the differences in ginger use between officers and soldiers. There was significant difference between soldiers and officers in all the tested variables: level of ginger awareness $(n=$ $337, M \pm S D=9.32 \pm 1.32, t(335)=4.94, M D=1.67, S E D=$ 1.02, $p=.001)$; health benefits from ginger intake $(n=337, M \pm$ $S D=t(335)=2.92, M D=0.94, p=0.004)$ and performance benefits from ginger intake $(n=337, t(335)=2.48, M D=0.45, p$ $=0.001)$. Despite reaching statistical significance, the magnitude of the differences was small $\eta^{2}=.007, .002$ and .002 for awareness, health and performance benefits respectively.

\section{Discussion}

The study investigated awareness and practice of ginger use among 337 students of Nigerian Army School of Education (NASE) Sobi-Ilorin, Kwara State. The awareness of ginger and ginger products among NASE, Sobi-Ilorin students was generally high. Majority of the respondents had seen and consumed ginger in different forms and for different health and performance benefits. 
Awareness of the benefit of Ginger use among Students of Nigeria Army School of Education, Sobil-Ilorin, Kwara State

Surh et al., (1999) that ginger is a common dietary condiment that has been consumed over a thousand, it was found in this study that few of the students actually used ginger as often as daily, and a fewer of them used it weekly or monthly.

It was revealed that the officers had seen and taken ginger drink more than soldiers did. However, more soldiers $(25.4 \%)$ used ginger daily than officers $(19.0 \%)$ did but on weekly and monthly basis; the officers $(27.6 \%$ and $18.1 \%)$ used it more than the soldiers $(22.0 \%$ and $14.2 \%)$ respectively. Since ginger is used for diverse purposes, this disparity between soldiers and officers might be due to the level of interaction, their cultural backgrounds and/or nutritional practices in the different units they had been posted to serve within the army. This corroborates the assertion of Gosh, (2011) that ginger is used in different ways including boosting appetite, alleviating cold and nausea.

The finding also revealed that more soldiers used ginger for relieving pain $(58.2 \%)$ and stimulating appetite $(65.1 \%)$ than officers $(36.2 \%$ and $44.8 \%)$ respectively. The nature of soldiers' job requires them to be on the fields always while officers perform their job mainly from the office excluding the few on special duties. Since ginger has different bioactive compounds that yield several health benefits, the soldiers could have observed this and used ginger more because of their higher exposure to health hazards while on the fields. The high level of ginger usage as well as the little disparity in use, confirms the postulations of Nafiseh et al, (2013), Nicoll and Henein (2009) and Ali et al, (2008) that ginger has remarkable benefits for health and treatment of ailments. So also among the students based on their cultural, social, occupational setting and health needs.

Majority of the soldiers preferred to use ginger for boosting stamina, activeness and alertness more than the officers did. It is well established that the physical demand of the military's job requires high level of fitness and alertness for optimal performance at all times. While this is crucial in military training, the soldiers of NASE, Sobi-Ilorin proved to be using ginger more than the officers to minimise fatigue, boost stamina and alertness which is 
crucial for their job as revealed in table 3 . This finding is similar to the view of Nafiseh et al (2013) and Bentley et al (2012) that ginger intake increases exercise performance among humans. This might be one of the reasons why soldiers whose occupation require optimal performance, activeness and alertness used ginger and its products daily unlike the officers whose duties are more from the office rather than the field.

\section{Conclusion}

Majority of the students had awareness of ginger and mainly consumed it as drink. Their frequency of use was generally low, just a few used it daily while even fewer of them used it weekly or monthly. The most common health benefits the NASE students derived using ginger was relieving pain, stimulating appetite, activeness and alertness. There was difference in the awareness, knowledge of benefit and use of ginger among officers and soldiers. The officers mostly consumed ginger to derive nutritional benefits but the soldiers used it for both nutritional and performance enhancement. We recommend that further studies should be carried out to elucidate the specific benefit of ginger on the health and performance of NASE students, the general military performance and the appropriate time of use and dosage regimen in order to avert possible adverse effect of ginger overuse.

\section{References}

Akram, M.M., Ibrahim, S., Khan, U.E., Mohiuddin, A., Sami, M., Asif, S.M., Ali, S., Khalil, A. \&Ghazala, S. (2011). Zingiber officinale Roscoe (A Medicinal Plant), Pakistan journal of. Nutrition, 10 (4), 399-400.

Ali, B.H., Blunden, G., Tanira, M.O. \& Nemmar, A. (2008). Some phytochemical, pharmacological and toxicological properties of ginger (Zingiber officinale Roscoe): A review of recent research. Food Chem Toxicol., 46(2), 409-20. 
Awareness of the benefit of Ginger use among Students of Nigeria Army School of Education, Sobil-Ilorin, Kwara State

Ahmed, R.S., Suke, S.G., Seth, V., Chakraborti, A., Tripathi, A.K. \& Banerjee, B.D. (2008). Protective effects of dietary ginger (Zingiber officinales Rosc.) on lindane-induced oxidative stress in rats. Phytother Res, 22(7), 902-6.

Amina A.A., Lami S.J., Usman B.L., Christiana T.A.K., \& Halima M.K. (2014). Why popularity of local beverages is soaring.

Bailey-Shaw, Y.A., Williams, L.A., Junor, G.A., Green, C. E., Hibbert, S.L., Salmon, C.N. \& Smith, A.M. (2008). Changes in the contents of oleoresin \& pungent bioactive principles of Jamaican ginger (Zingiber officinale Roscoe) during maturation. J Agric Food Chem., 56(14), 5564-71.

Bentley, D.J., Dank, S., Coupl, R., Midgley, A. \&Spence, I. (2012). Acute antioxidant supplementation improves endurance performance in trained athletes. Res Sports Med, 20, 1-12.

Chukwuma, M. (2015). Shea nut oil, turmeric, others top list of local plants for joints pains. Retrieved from www.guardian.ng 17 January 2017.

Cohen, R. J., Ek, K. \& Pan, C.X. (2002). Complementary \& alternative medicine use by older adults: A comparison of self-report \& physician chart documentation. J Gerontol A Biol Sci Med Sci, 57(4):M223-7.

El-Abhar, H.S., Hammad L.N. \& Gawad, H.S. (2008). Modulating effect of ginger extract on rats with ulcerative colitis. Journal of Ethnopharmacol. 118(3), 367-72.

El-Sharaky, A.S., Newairy, A.A., Kamel, M.A. \& Eweda, S.M. (2009). Protective effect of ginger extract against bromobenzene-induced hepatotoxicity in male rats. Food Chem Toxicol., 47(7), 1584-90.

Ferguson, P. (2014). History of Gimgerbread Men. Archived from original on 7 August 2013.

Ghayur, M.N. \& Gilani, A.H. (2005). Pharmacological basis for the medicinal use of ginger in gastrointestinal disorders. Dig Dis Sci., 50(10), 1889-97. 
Ghayur, M. N., Gilani, A.H., Ahmed, T., Khalid, A., Nawaz, S.A., Agbedahunsi, J. M., Choudhary, M.I. \& Houghton, P.J. (2008). Muscarinic, $\mathrm{Ca}(++)$ antagonist \& specific butyrylcholinesterase inhibitory activity of dried ginger extract might explain its use in dementia. Journal of Pharm Pharmacol., 60(10), 1375-83.

Ghosh, A.K. (2011). Zingier officinale: A natural Gold. International Journal of Pharma \& Bioscience. 2 (1).

Halvorsen, B.L. (2002). A systematic screening of total antioxidants in dietary plants. $J$ Nutr. 132(3), 461-71.

Jolad, S.D., Lantz, R.C., Chen, G.J., Bates, R.B. \& Timmermann, B.N. (2005). Commercially processed dry ginger (Zingiber officinale): Composition and effects on LPSstimulated PGE2 production. Phytochemistry, 66(13), 1614-35.

Koh, E.M., Kim, H.J. \& Kim, S. (2009). Modulation of macrophage functions by compounds isolated from Zingiber officinale. Planta Med. 75(2):148-51.

Minghetti, P., Sosa, S. \& Cilurzo, F. (2007). Evaluation of the topical anti-inflammatory activity of ginger dry extracts from solutions \& plasters. Planta Med. 73(15), 1525-30.

Mashhadi N. S., Ghiasvad R., Askari G., Hariri M., Darvish L., \& Mofid M. R. (2013). Anti-oxidative and antiinflammatory effects of ginger in health and physical activity. Retrieved January 2017.

Matsumura M. D., Zavorsky G. S. \& James M.S. (2015). The effect of pre-exercise ginger supplementation on muscle damage and delayed onset muscle soreness.

Nafiseh, S.M., Reza, G., Mitra, H., Gholamreza, A., Awat, F., Leila, D., Maryam, H. \& Azam, B. (2013). Effect of Ginger \& Cinnamon Intake on Oxidative Stress \& Exercise Performance \& Body Composition in Iranian Female Athletes. International Journal ofPreventive Medicine, 4(1), 31-35.

Nicoll, R., \&Henein, M. Y. (2009). Ginger (Zingibe rofficinale Roscoe): A hot remedy for cardiovascular disease? Int $J$ Cardiol. 131(3), 408-9. 
Awareness of the benefit of Ginger use among Students of Nigeria Army School of Education, Sobil-Ilorin, Kwara State

Quimby, E.L. (2007). The use of herbal therapies in paediatric oncology patients: Treating symptoms of cancer \& side effects of st\&ard therapies. Journal of Pediatr Oncol Nurs., 24(1), 35-40.

Reginster, J. Y., Gillot, V., Bruyere, O. \&Henrotin, Y. (2000). Evidence of nutriceutical effectiveness in the treatment of osteoarthritis. Curr Rheumatol Rep., 2(6), 472-7.

Thompson, H.J. \& Potter P.J. (2006). Review: Ginger prevents 24hour postoperative nausea \& vomiting. Evid Based Nurs. 9(3) 80.

Topic, B., Tani E., Tsiakitzis, K., Kourounakis, P.N., Dere, E., Hasenohrl, R. U., Hacker, R., Mattern, C.M. \& Huston, J.P. (2002). Enhanced maze performance \& reduced oxidative stress by combined extracts of Zingiber officinale\& ginkgo biloba in the aged rat. Neurobiol Aging., 23(1), 135-43.

Wu, K.L., Rayner, C.K., Chuah, S.K. (2008). Effects of ginger on gastric emptying \& motility in healthy humans. Eur Journal of Gastroenterol Hepatol 20 (5), 436-40.

Nutritionist-resource, (2017). Sport nutrition. Retrieved Febuary 20, 2017 from www.nutritinist-resource.ng.uk.

Naijabizcom, (2011). How to export ginger from Nigeria. Retrieved January 20, 2017 from www.naijabizcom.com.

Young, H.Y., Luo, Y. L., Cheng, H.Y., Hsieh, W.C., Liao, J.C. \& Peng, W.H. (2005). Analgesic \& anti-inflammatory activities of [6]-gingerol. Journal of Ethnopharmacol (1(2), 207-10. 